University of Nebraska - Lincoln

DigitalCommons@University of Nebraska - Lincoln

Papers in the Earth and Atmospheric Sciences Earth and Atmospheric Sciences, Department

4-15-2002

\title{
Late-Quaternary lowstands of Lake Titicaca: Evidence from high- resolution seismic data
}

\author{
Karin D'Agostino \\ Syracuse University \\ Geoffrey Seltzer \\ Syracuse University \\ Paul A. Baker \\ Duke University, pbaker@duke.edu \\ Sherilyn C. Fritz \\ University of Nebraska-Lincoln, sfritz2@unl.edu \\ Robert Dunbar \\ Stanford University, Stanford, CA
}

Follow this and additional works at: https://digitalcommons.unl.edu/geosciencefacpub

Part of the Earth Sciences Commons

D'Agostino, Karin; Seltzer, Geoffrey; Baker, Paul A.; Fritz, Sherilyn C.; and Dunbar, Robert, "Late-Quaternary lowstands of Lake Titicaca: Evidence from high-resolution seismic data" (2002). Papers in the Earth and Atmospheric Sciences. 35.

https://digitalcommons.unl.edu/geosciencefacpub/35

This Article is brought to you for free and open access by the Earth and Atmospheric Sciences, Department of at DigitalCommons@University of Nebraska - Lincoln. It has been accepted for inclusion in Papers in the Earth and Atmospheric Sciences by an authorized administrator of DigitalCommons@University of Nebraska - Lincoln. 
Published in Palaeogeography, Palaeoclimatology, Palaeoecology 179:1-2 (April 15, 2002), pp. 97-111; doi:10.1016/S0031-0182(01)00411-4 http://www.sciencedirect.com/science/journal/00310182

Copyright (C) 2002 Elsevier Science B.V. Used by permission.

Submitted March 20, 2000; accepted September 14, 2001; published online March 22, 2002.

\title{
Late-Quaternary lowstands of Lake Titicaca: Evidence from high-resolution seismic data
}

\author{
Karin D’Agostino a,1, Geoffrey Seltzer ${ }^{\mathrm{a}, 2}$, Paul Baker ${ }^{\mathrm{b}}$, \\ Sherilyn Fritz ${ }^{\mathrm{c}}$, and Robert Dunbar ${ }^{\mathrm{d}}$ \\ a Department of Earth Sciences, Syracuse University, Syracuse, NY 13244-1090, USA \\ b Division of Earth and Ocean Sciences, Duke University, Durham, NC 27708, USA \\ c Department of Geosciences, University of Nebraska-Lincoln, Lincoln, NE 68588, USA \\ ${ }^{\mathrm{d}}$ Department of Geological and Environmental Sciences, \\ Stanford University, Stanford, CA 94305, USA \\ ${ }^{1}$ Present address: ExxonMobil Exploration Company, Houston, TX, USA. \\ ${ }^{2}$ Corresponding author — fax 315 443-3363; email goseltze@syr.edu
}

\begin{abstract}
Approximately $600 \mathrm{~km}$ of high-resolution seismic reflection data were collected to investigate the late-Quaternary stratigraphic development of Lake Titicaca. The focus of this report is on two seismic sequence boundaries, which are interpreted as erosional surfaces formed at times of low lake level. The younger erosional surface occurs as much as $90 \mathrm{~m}$ below the present lake level and up to $8 \mathrm{~m}$ below the present sediment-water interface. This erosional surface is interpreted to be coeval with a well-documented early- to mid-Holocene lowstand, dated between $~ 8,000$ and $3,600 \mathrm{cal}$ yr BP. An earlier and previously unknown erosional surface occurs at a sub-bottom depth of approximately $30 \mathrm{~m}$, and as much as $240 \mathrm{~m}$ below the present lake level, which implies a major late-Pleistocene lowstand of Lake Titicaca. By extrapolation of sedimentation rates from the upper $\sim 14 \mathrm{~m}$ of sediment, we estimate the age of this older lowstand at $>90,000 \mathrm{cal} \mathrm{yr} \mathrm{BP.} \mathrm{Both} \mathrm{lowstands} \mathrm{of} \mathrm{Lake} \mathrm{Titicaca} \mathrm{indicated} \mathrm{by} \mathrm{the} \mathrm{seismic} \mathrm{data} \mathrm{are} \mathrm{likely} \mathrm{to} \mathrm{have} \mathrm{been}$ a response to climatic change in the region.
\end{abstract}

Keywords: Andes, Lake Titicaca, lake level change, seismic reflection data, tropical paleoclimate

\section{Introduction}

Lake Titicaca is an important site for paleoclimatic research in the South American tropics because of the evidence for major lake level changes in the late Quaternary (e.g., Newell, 1949; Kessler, 1985; Wirrman, 1992; Abbott et al., 1997; Binford et al., 1997; Seltzer et al., 1998; Cross et al., 2000; and Baker et al., 2001a). Despite having an outlet, the
Río Desaguadero (Figure 1), most of the water loss from Lake Titicaca today is by evaporation (Roche et al., 1992), making the lake a nearly closed basin and increasing the sensitivity of the hydrologic mass balance of the lake to climate change. Lake level changes and related geochemical evolution of the basin have had a profound impact on sedimentary carbon, carbonates, and diatoms (Cross et al., 2000; Baker et al., 2001a). Furthermore, the 


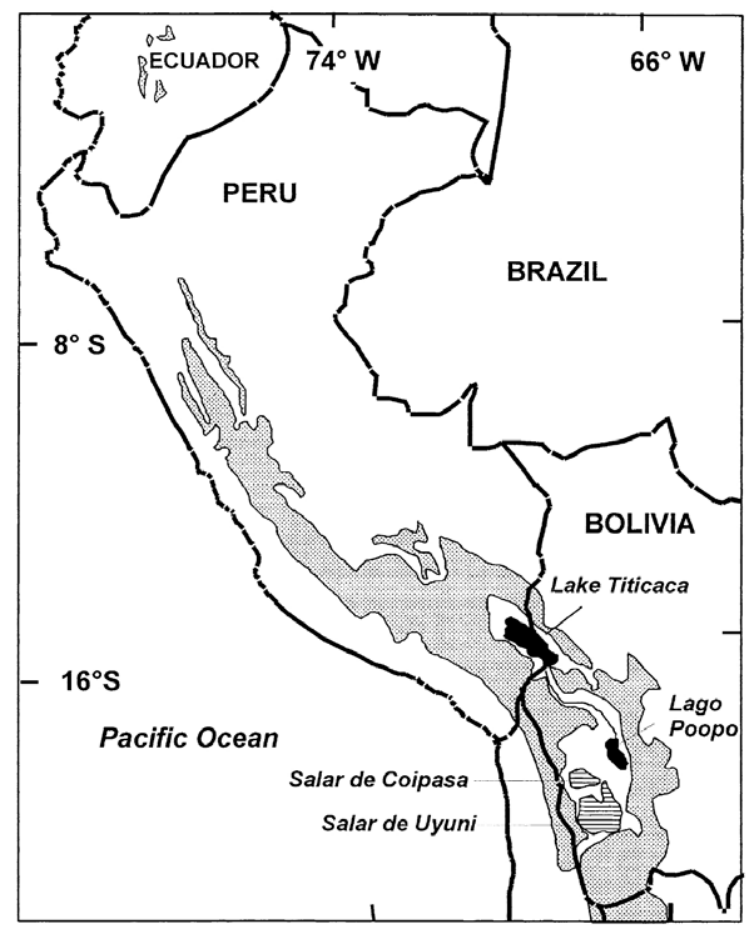

Figure 1. Location map for Lake Titicaca. Shaded area is $>4,000 \mathrm{~m}$ a.s.l.

presence of nearby alpine glaciers makes the detrital flux of sediments to the lake a sensitive recorder of tropical glaciation (e.g., Mercer, 1984; Seltzer, 1992; and Seltzer, 1994). Besides the impact of climatic change, the lake and the surrounding Altiplano are also affected by neotectonic activity associated with uplift and extension of the central Andes (Newell, 1949; Sebrier et al., 1985; and Lavenu, 1992). Here we use the first seismic reflection data obtained from the lake (e.g., Seltzer et al., 1998) to investigate the recent stratigraphic development of Lake Titicaca and therefore the record of late-Quaternary climatic and tectonic change in the tropical Andes.

\section{Study area}

The Altiplano is a high-altitude, endorheic basin, $200,000 \mathrm{~km}^{2}$ in area, that occupies the inter-cordilleran region of Bolivia and southern Peru (Figure 1). The northern Altiplano is occupied by Lake
Titicaca (3,809 m a.s.l.). During high lake stands, Lake Titicaca drains via the Río Desaguadero to the shallow and saline Lago Poopó. In turn, during past wet periods, Lago Poopó was hydrologically connected with the presently dry salares (salt pans) of Uyuni and Coipasa (Figure 1). Recently, 15,000-25,000 cal yr BP (calendar years before present), the latter three basins were joined to form paleolake Tauca on the southern Altiplano (Servant et al., 1995; Baker et al., 2001b). The hydrologic system reflects a strong modern precipitation gradient from the wet northern Altiplano ( $\sim 800 \mathrm{~mm} / \mathrm{yr}$ mean precipitation) to the arid central and southern Altiplano $(<100 \mathrm{~mm} / \mathrm{yr}$ mean precipitation).

The Strait of Tiquina connects the two modern sub-basins of Lake Titicaca, the larger and deeper (up to 285 m) Lago Grande (or Lago Chucuito), and the smaller and shallower (up to $40 \mathrm{~m}$ ) Lago Menor (or Lago Huiñaimarca) (Figure 2). At its current level, the surface of the lake covers $~ 8,500$ $\mathrm{km}^{2}$ (Boulangé and Aquize Jean, 1981). Five tributary rivers (Ríos Ramis, Huancané, Suchez, Ilave and Coata) drain most of the $57,000 \mathrm{~km}^{2}$ watershed of Lake Titicaca. The outflow of Lake Titicaca is controlled by a number of hydrologic sills. The outlet from Lago Menor at the Río Desaguadero has a sill at $3804 \mathrm{~m}$ a.s.l. A second sill is located at an elevation of 3,788 $\mathrm{m}$ a.s.l. in the Strait of Tiquina. When lake level drops below this elevation, hydrologic exchange between Lago Menor and Lago Grande ceases (Wirrman, 1992).

\section{Methods}

Approximately $600 \mathrm{~km}$ of high-resolution, seismic reflection data were obtained in 1996 on board the RV Yakuza (Figure 3). The data were collected using an Edge-Tech X-Star sub-bottom profiler, with a pulse-band width of $2-12 \mathrm{kHz}$. Assuming a velocity of $1500 \mathrm{~m} / \mathrm{s}$ of sound in water and in the uppermost sediments, the expected maximum vertical resolution for this frequency band is about $0.15 \mathrm{~m}$. Maximum acoustic penetration was $\sim 50 \mathrm{~m}$ of sediment, although on average only the upper $30 \mathrm{~m}$ were imaged. Most of the seismic lines were located in the shallower re- 


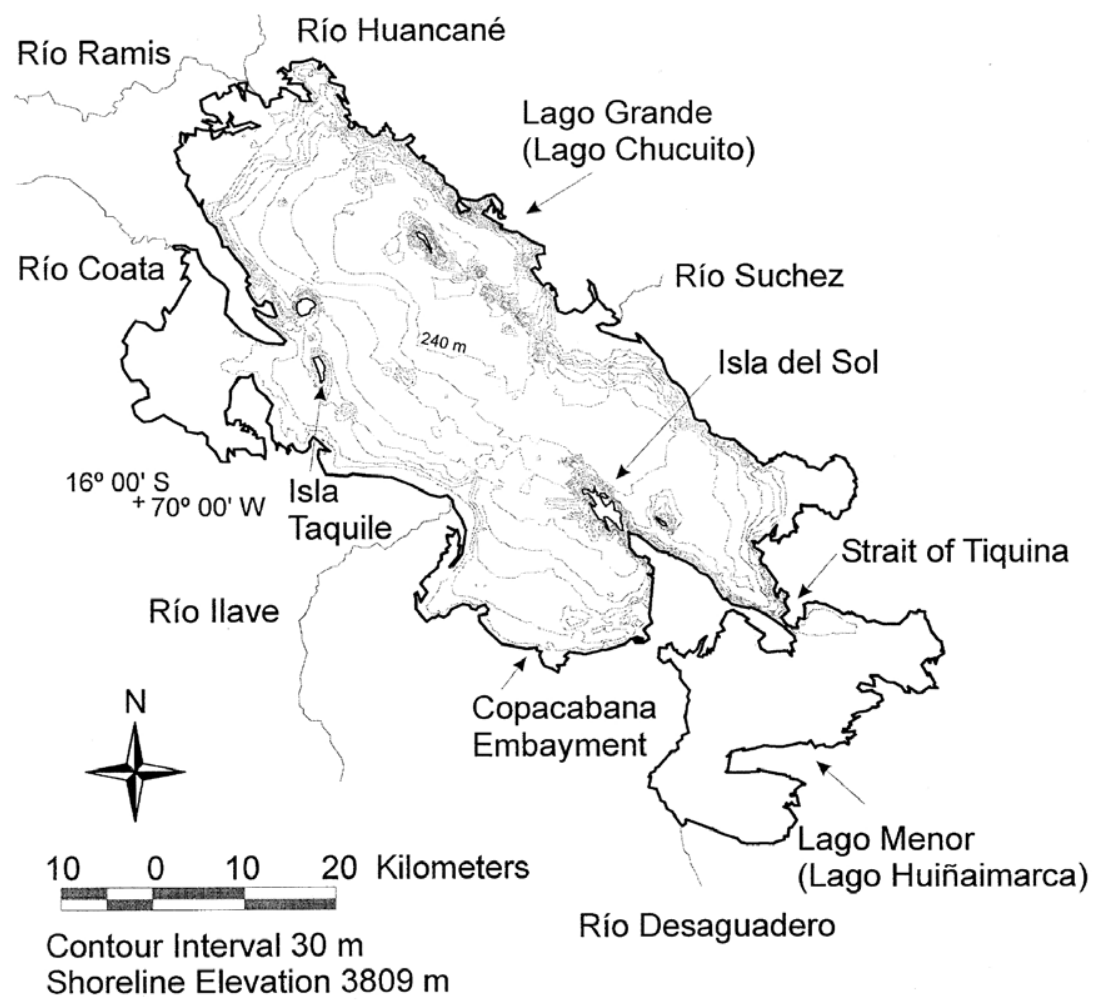

Figure 2. Bathymetry of Lake Titicaca. This map was created using approximately 5,000 depth soundings from five nautical joint Peruvian-Bolivian maps with a 1:100,000 scale. The data were entered into ARC/INFO in order to generate a triangulated irregular network and were then contoured.

gions of the lake, with a few crossing lines obtained in deeper regions to provide correlation of basinwide events and to examine deeper water sequence stratigraphy. A handheld global positioning satellite receiver operating in autonomous mode was interfaced with the seismic system providing positional accuracy of $<100 \mathrm{~m}$.

The interpretation of the seismic data followed procedures outlined by Vail et al. (1977) and Vail (1987). Sequence boundaries were defined by reflection terminations, such as convergence and truncation. Once the seismic sequences were defined and the bounding horizons mapped, the thickness of each sequence was measured by converting two-way travel time into sub-bottom depths, assuming a velocity of 1500 $\mathrm{m} / \mathrm{s}$ (D’Agostino, 1998). Because of the low density of seismic lines, traditional seismic stratigraphic analysis, including mapping of seismic facies and seismic reflection geometries, is not possible with this data set. Furthermore, although sequence boundaries were traced throughout the basin, isopach maps were not produced because of the sparseness of data.

Most of the published analyses of the sediments of Lake Titicaca (e.g., Boulangé et al., 1981; Wirrman and De Olivera Almeida, 1987; Abbott et al., 1997; and Cross et al., 2000) focus on the mid- to late-Holocene sedimentation of the lake. More recently, Baker et al. (2001a) analyzed the sedimentology and stratigraphy of several piston cores up to $14 \mathrm{~m}$ in length from locations throughout Lago Grande. Baker et al. identified detrital glacial sediments deposited in deep water between 30,000 and 20,000 cal yr BP indicative of the last glacial maximum. Deep water sediments also accumulated from 20,000 to $\sim 15,000 \mathrm{cal} \mathrm{yr}$ BP, 13,000 to $\sim 11,500$ cal yr BP, 10,000 to 8,000 


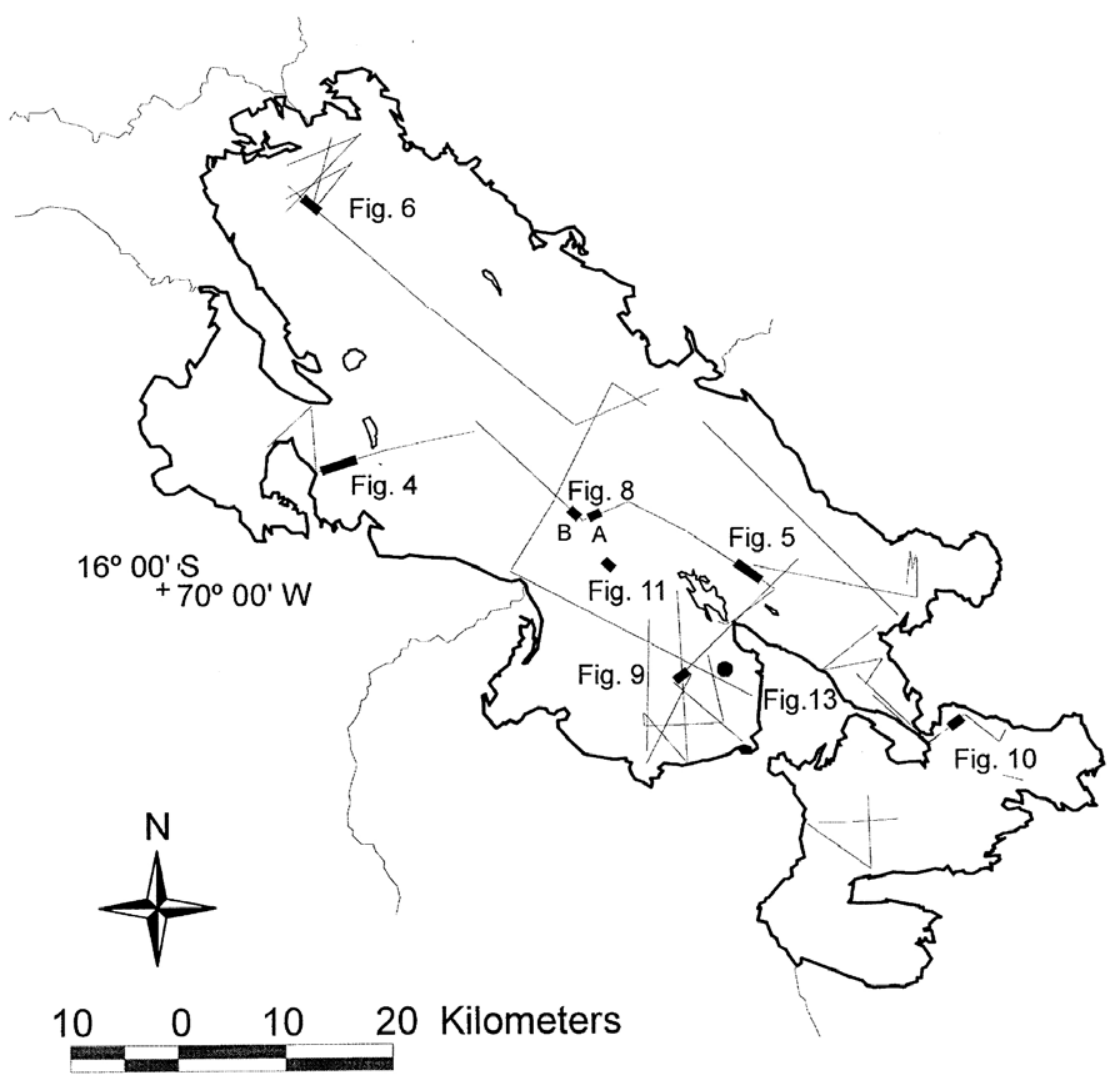

Figure 3. Location of seismic lines in Lake Titicaca. Locations of seismic data depicted in Figure 4, Figure 5, Figure 6, Figure 8, Figure 9, Figure 10 and Figure 11 are indicated by thick lines and the location of sediment core NE981PC and associated seismic data in Figure 13 is depicted by the solid circle.

cal yr BP, and 2,000 cal yr BP to the present. Interspersed with the periods of deep water sedimentation in the lake are relatively saline lake intervals characterized by the deposition of benthic diatoms and carbonates. The relatively saline lake intervals are interpreted as periods of time when the level of the lake dropped below its outlet and the sill at the Strait of Tiquina.

\section{Results}

\subsection{Lago Grande}

Within the upper $30 \mathrm{~m}$ of sediment penetrated by the acoustic signal, three seismic sequences can be defined (Figure 4). We refer to this group of three seismic sequences as the Taquile Sequence Set, named for Isla Taquile, which is near the seismic line where these sequences are best identified (Figure 2 and Figure 4). This designation helps to distinguish this group of seismic sequences from subsequent sequences that might be identified using a more powerful acquisition system with greater penetration.

The base of Sequence I is below the penetration of the acoustic signal and therefore the thickness of Sequence I is unknown at this time. The upper boundary of Sequence I is an erosional unconformity marked by truncation of reflections. Along the western shoreline, erosion along this boundary is found at depths as much as $\sim 130 \mathrm{~m}$ below the present lake level. In the Copacabana embayment, erosion along the boundary is found $175 \mathrm{~m}$ below the present lake level. East of Isla del Sol, several locations show an angular uncon- 


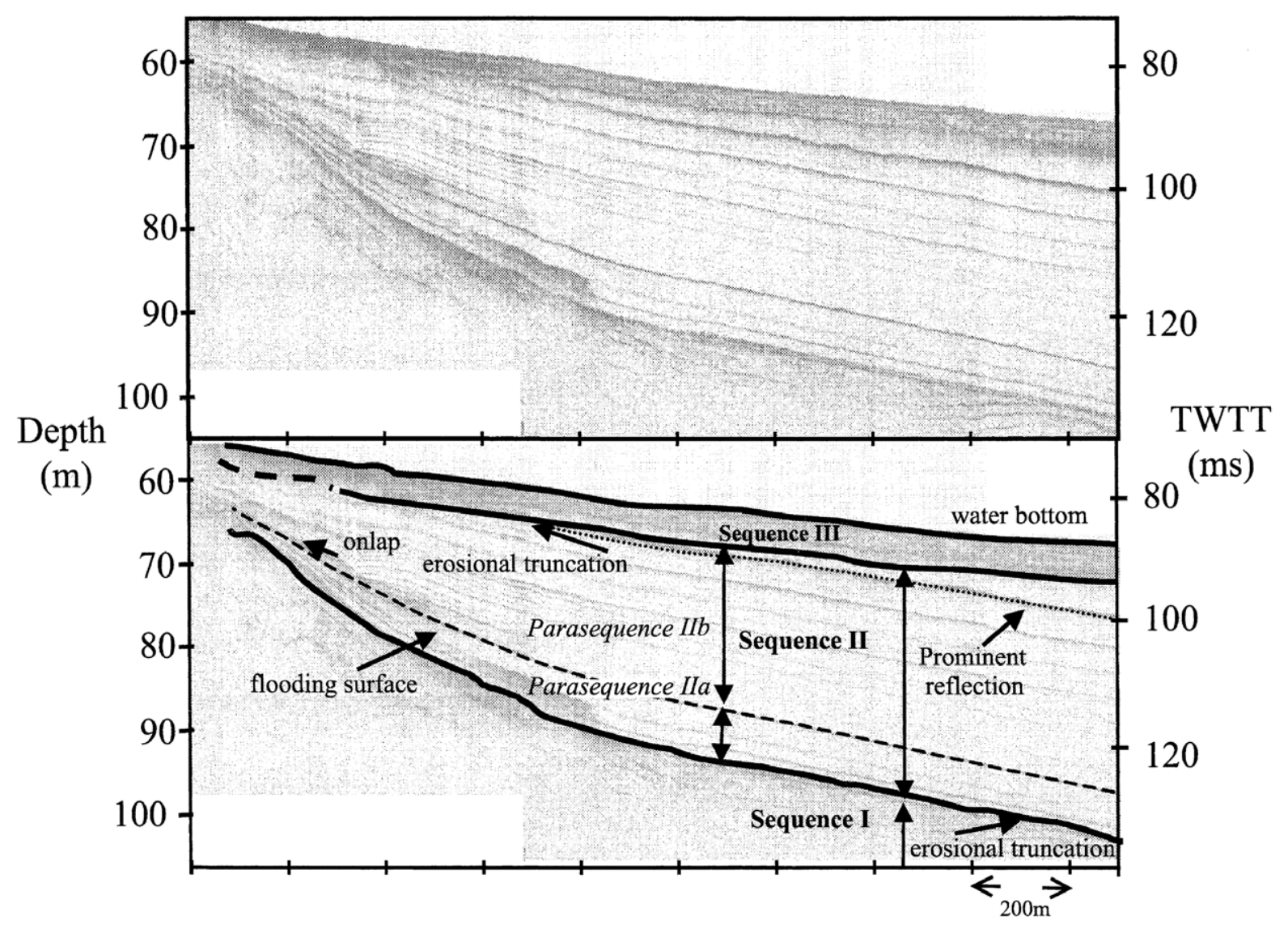

Figure 4. Seismic profile showing sequence boundaries in the Taquile Sequence Set. Seismic sequence boundaries are defined by erosional truncation of seismic reflections at the base of Sequences II and III.

formity at the upper boundary of Sequence I, as much as $240 \mathrm{~m}$ below the modern lake surface (Figure 5). Only in the deepest areas of the lake (from $200 \mathrm{~m}$ to $285 \mathrm{~m}$ modern water depth) do the sediments above this boundary appear to be conformable with Sequence I.

Sequence II is divided into two parasequences separated by a flooding surface. Roughly $5 \mathrm{~m}$ above the base of Sequence II there is a strong reflection with no evidence of erosion below, but onlap above (Figure 4). This reflection is interpreted as a flooding surface that represents lake level rise. The top of Sequence II is defined by an erosional unconformity found at two locations in the basin. In the nearshore area north of the Ilave delta, the top of Sequence II is eroded in depths as great as 90 m below modern lake level. In the Huancané delta, erosion truncates an antiform of Sequence II sediments, at approximately $90 \mathrm{~m}$ below lake level (Figure 6).

The seismic signature of Parasequence IIa within Sequence II is characterized by an approximately 2-m-thick package of closely spaced highamplitude reflections. The acoustic stratigraphy in Parasequence IIb consists of evenly spaced low- to medium-amplitude reflections. The upper $7 \mathrm{~m}$ of Sequence II contain a number of high-amplitude reflections, which are most apparent in the deeper regions of the lake.

Near the top of Sequence II is a prominent basinwide reflection at an average sub-bottom depth of 10 m (Figure 4 and Figure 5). Seismic reflection data do not indicate a sequence boundary along this reflection, as there is no evidence of 


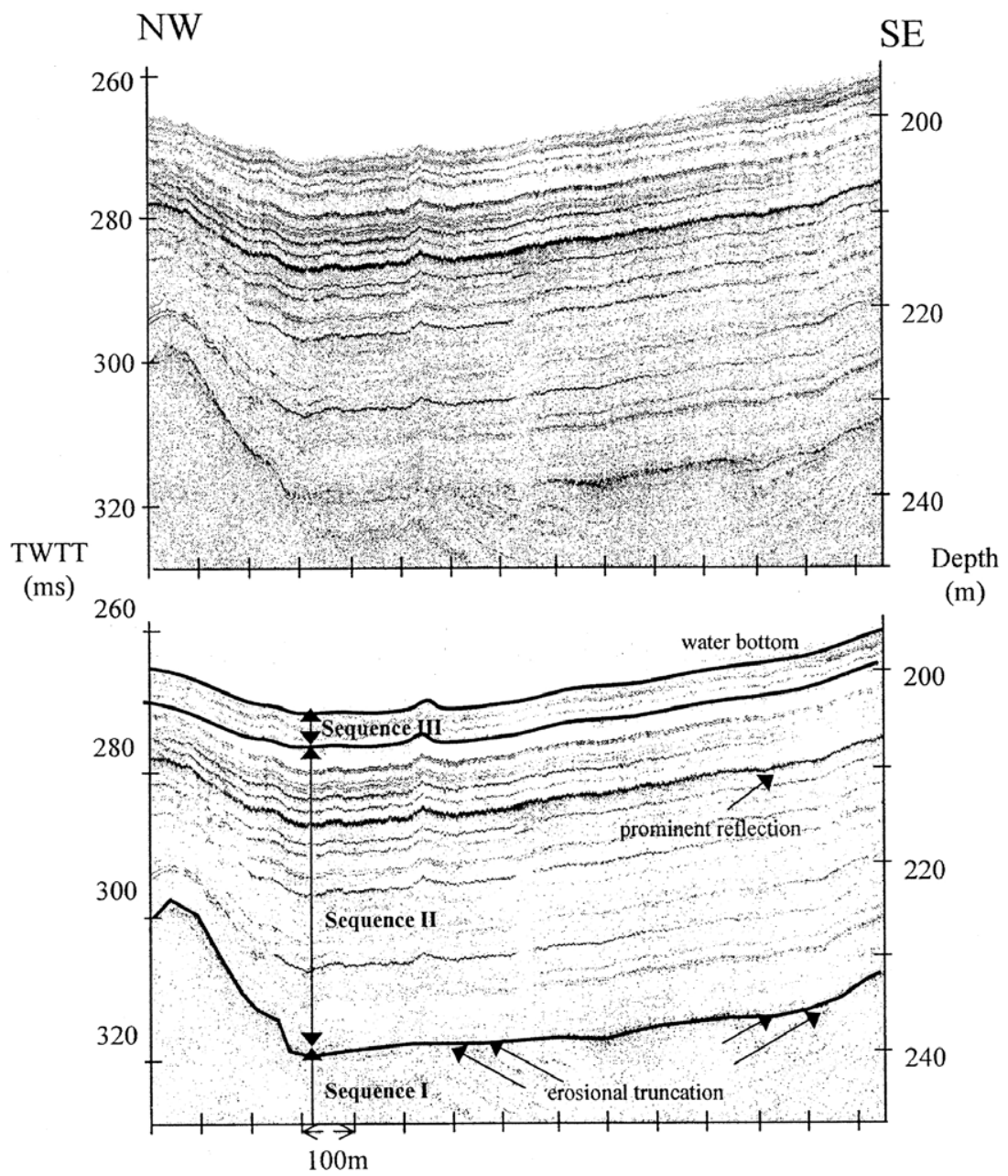

Figure 5. Seismic profile showing erosional truncation at the top of Sequence I in $200 \mathrm{~m}$ water depth.

erosion below, or onlap or downlap above the reflection. Furthermore, the reflection does not appear to be the boundary between two distinct seismic facies. The characteristics of the reflection are unique and easily recognizable as the highest-amplitude and most continuous reflection on most seismic profiles. The amplitude of the reflection is consistent throughout the basin even in a variety of depositional environments. Diffractions are common along this reflection, indicating that in places it is an uneven or discontinuous surface.

The erosion surface at the top of Sequence II forms the base of Sequence III. The sediment-water interface defines the top of Sequence III. The reflection geometry of Sequence III is relatively uniform throughout the basin. The vertical succession of seismic facies is characterized by two packages. In many areas, two equally spaced, relatively low-amplitude reflections are found immediately above the basal boundary and are themselves overlain by a high-amplitude reflection (Figure 4). This lower package of Sequence III is about 1-2 m thick. The stratigraphic section between the high-amplitude reflection and the sediment surface contains closely spaced, medium- to high-amplitude reflections, especially in shallower areas. Onlap occurs in a few locations within this uppermost package, especially around the Huan- 
SE
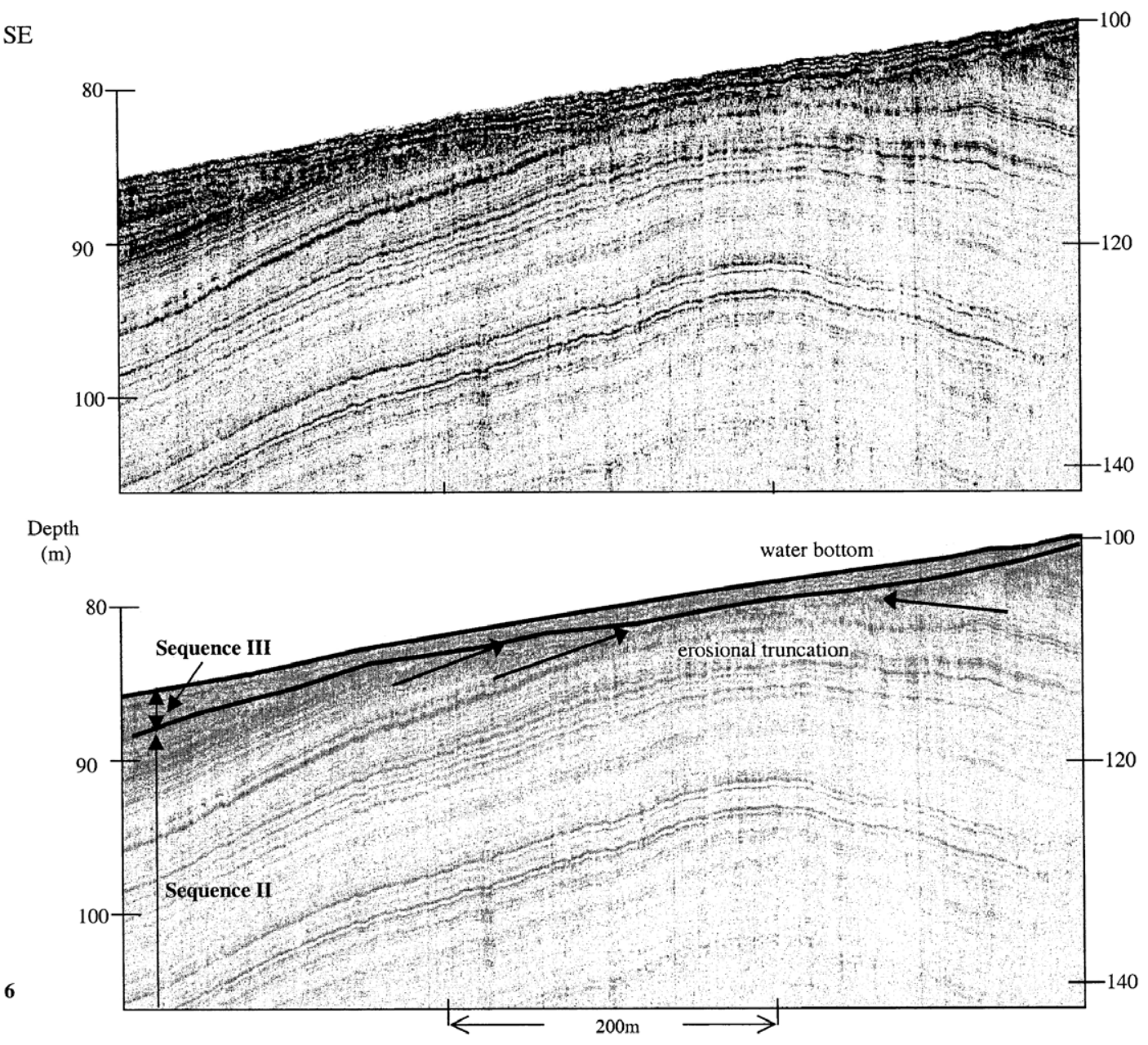

Figure 6. Seismic profile showing erosional truncation at the top of Sequence II in the Río Ramis-Huacané delta.

cané delta, suggesting relatively recent lake level variations.

The thickness of the seismic sequences consistently shows that the rate of sediment accumulation was lowest in the Copacabana embayment, most likely because no modern rivers feed directly into this section of the lake. Because the basal boundary of Sequence I was not imaged, the thickness of Sequence I cannot be determined. Although thinning in shallower regions, Sequence II has a uniform thickness of close to $30 \mathrm{~m}$ throughout the deeper sections of Lago Grande. The subbottom depth of the prominent reflection in Sequence II varies from 6 to $12 \mathrm{~m}$. Sequence III is as much as $8 \mathrm{~m}$ thick; highest accumulation rates occur close to the deltas (where data are available) and the average thickness is $4 \mathrm{~m}$.

The depth distribution of morphologic channels at the sediment-water interface where they cross the seismic profiles is approximately bimodal, at $\sim 50 \mathrm{~m}$ and $210 \mathrm{~m}$ water depth (Figure 7). Most channels are located offshore from modern deltas. The channels in shallower areas likely formed by subaerial erosion of Sequence II during the lateGlacial to mid-Holocene lowstand (Seltzer et al., 1998) and in places only contain a thin drape of Sequence III sediment. The deeper channels may be of sub-lacustrine origin as they are not clearly 


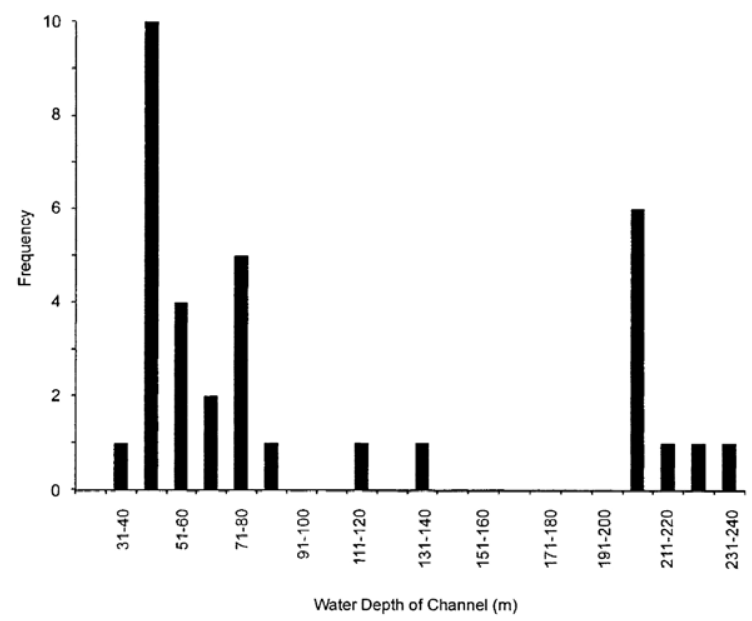

Figure 7. Histogram of channels at the sediment-water interface observed in the seismic data as a function of water depth $(n=36)$.

related to other evidence for lake level lowering. The deeper channels have also incised Sequence II, but they contain a thicker drape of recent sediments that may constitute all of Sequence III (Figure 8). Thus, the channels found in deep water may predate the middle-Holocene lowstand of the lake. There is a notable absence of channels in water depths between 140 and $205 \mathrm{~m}$.
There is little evidence of structural deformation of the shallow sediments. Several antiforms are present (e.g., Figure 6), but because of limited sub-bottom penetration, it is impossible to determine whether they are due to compression or are sediments simply draped over bedrock highs. The seismic data reveal faults in the shallow sediments, with a maximum offset of about $1 \mathrm{~m}$ (Figure 9). The throw of most faults decreases up section and sometimes disappears completely towards the lake floor. In limited areas, where bedrock is imaged, some faults are found near bedrock highs and might be part of the basin-scale tectonic framework. In most areas, however, the bedrock surface was not penetrated by the acoustic signal, leaving the relationship between faults and basin evolution unclear.

\subsection{Lago Menor}

The seismic coverage of Lago Menor is limited. Many areas of the basin lie in less than $5 \mathrm{~m}$ of water, with a maximum water depth of $\sim 40 \mathrm{~m}$. Because Lago Menor was mostly desiccated and was separated from Lago Grande during much of the early and mid Holocene (Wirrman et al., 1992; Abbott et al., 1997), its stratigraphic development

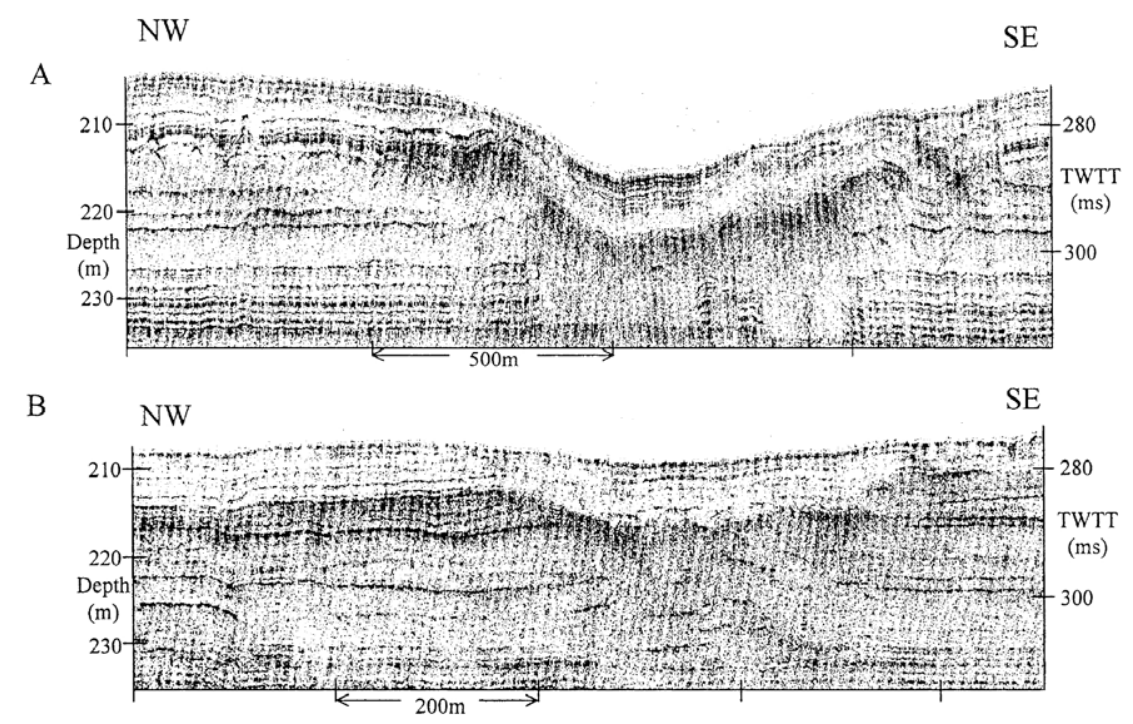

Figure 8. Seismic profiles showing channels west of the Ilave delta in $\sim 200 \mathrm{~m}$ water depth. Both channels contain several meters of sediment that may constitute most of Sequence III. The channels are eroded into the top of Sequence II. 


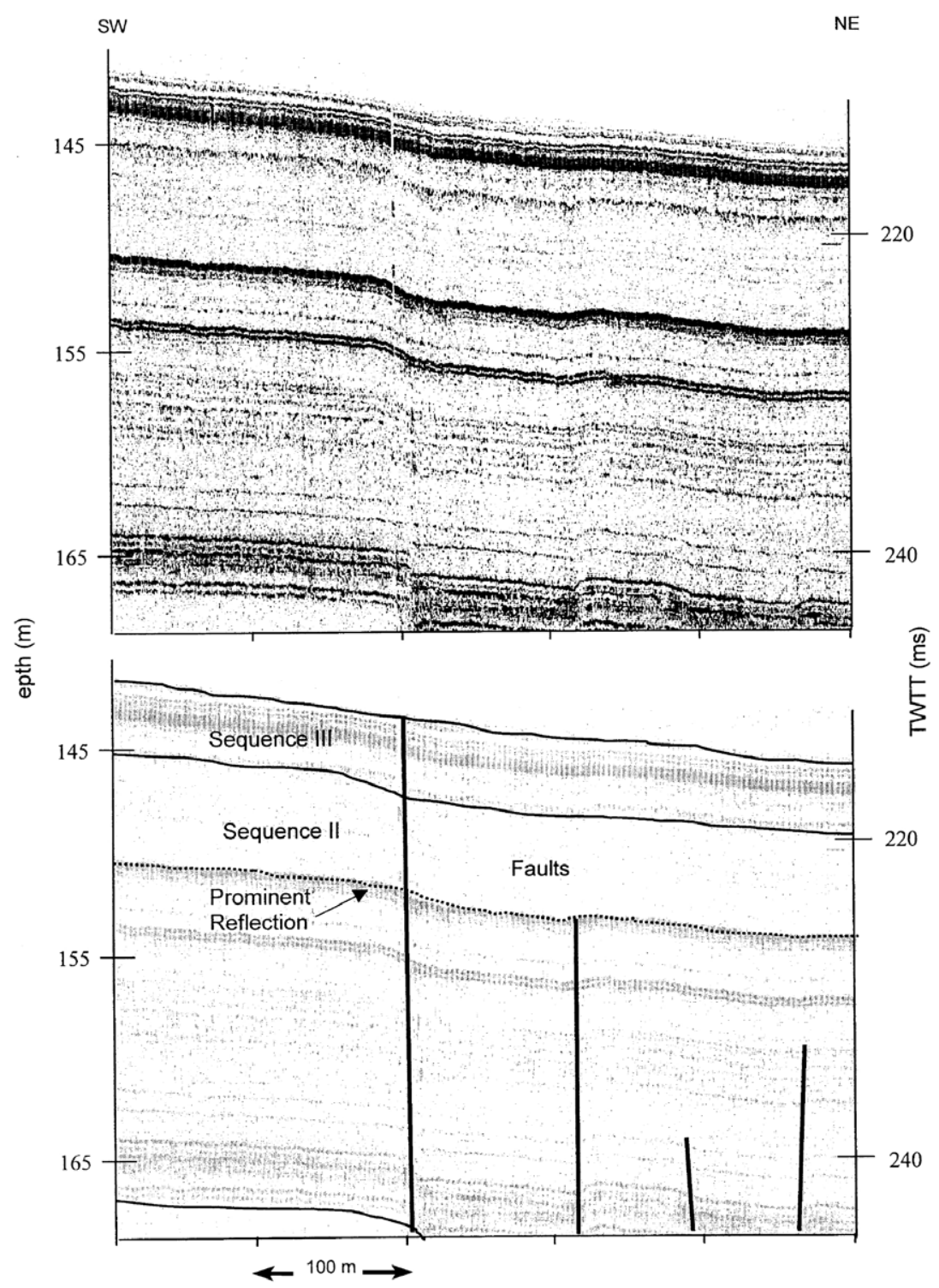

Figure 9. Seismic profile showing high-angle normal faults and sediment stratigraphy in the Copacabana embayment.

differed from Lago Grande, making correlation of seismic sequences between the two basins difficult. High-amplitude, closely spaced reflections are observed in the upper few meters of the seismic sequence throughout much of the Lago Menor basin. Below the upper few meters, both the frequency of reflections and their amplitude decrease. An erosional surface, representing the late-Glacial to early-Holocene unconformity (e.g., Abbott et al., 1997) is found at 2-7 m sub-bottom (Figure 10). Desiccation in the middle Holocene produced distinctive erosional surfaces that have been buried by relatively little sediment since flooding of Lago Menor (Seltzer et al., 1998).

\section{Discussion}

Little can be inferred about the nature of Sequence I, because no sedimentologic data and limited acoustic data are available. The dynamics that caused the non-horizontal strata in the seismic data 


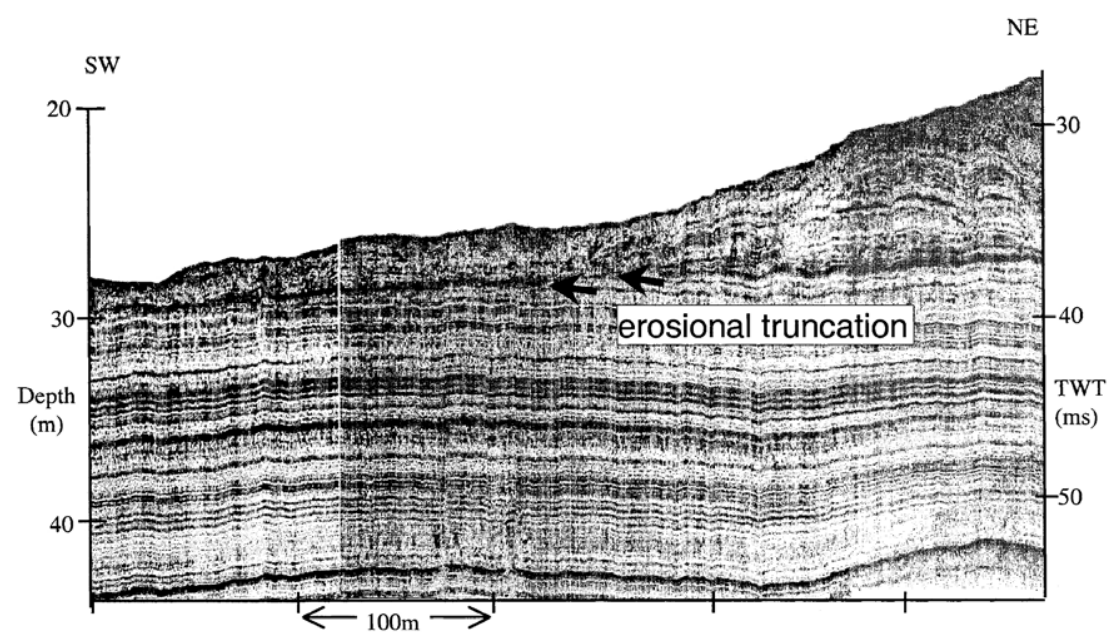

Figure 10. Seismic profile showing erosional truncation of seismic reflections in Lago Menor.

within Sequence I in many locations cannot be determined. Possible mechanisms include structural deformation or, more likely, sediment drape over structural highs. In the deeper areas of the basin (>200 m modern water depth), where Sequence I is present in the seismic profiles, the reflections appear to be continuous and conformable with the overlying strata, indicating relatively undisturbed deep water sedimentation.

The limits of acoustic penetration of the seismic data nearly coincide with the top boundary of Sequence I. This erosional boundary suggests a significant change in the depositional mode of the lake. Evidence of erosion along this boundary is

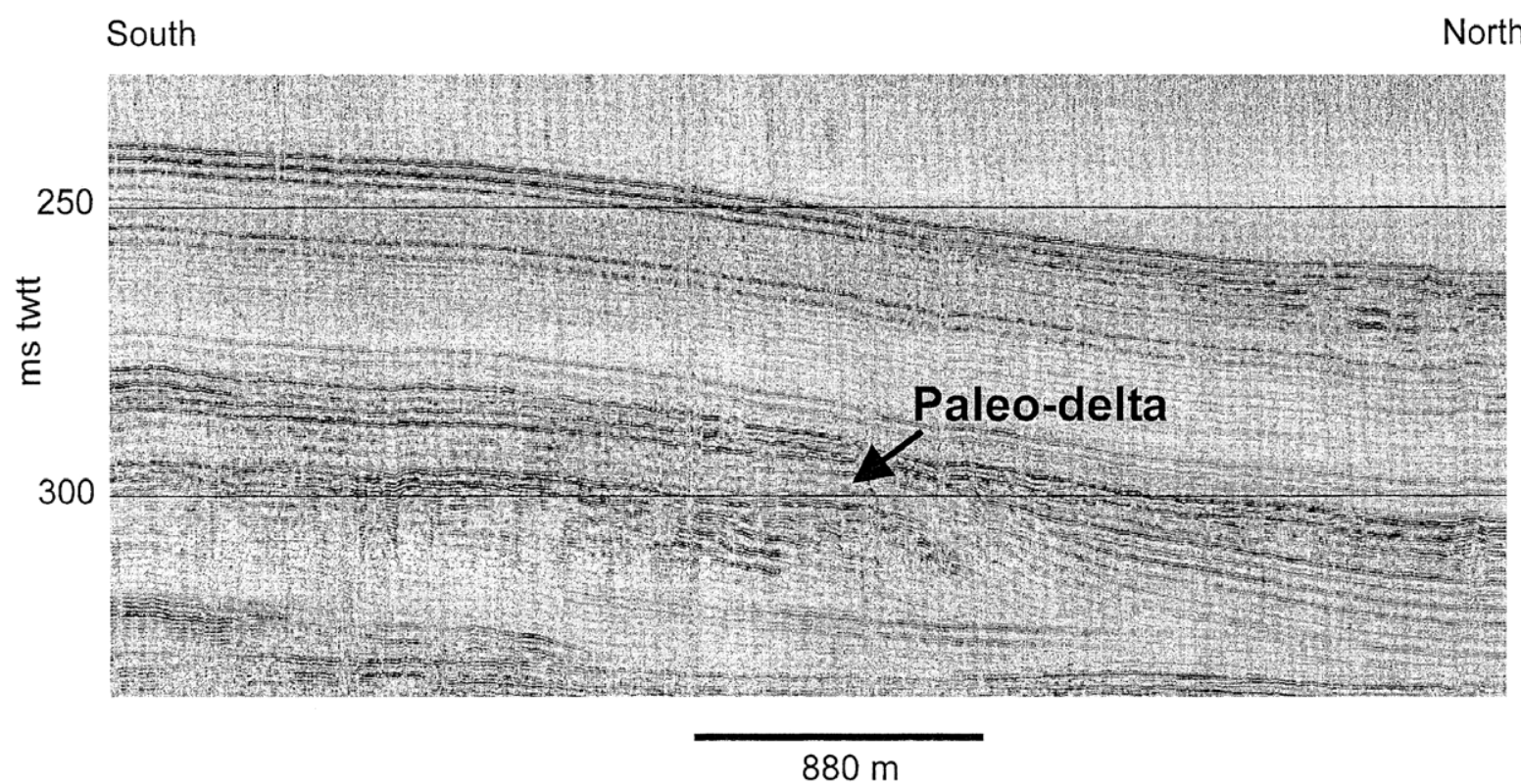

Figure 11. Seismic profile showing clinoforms interpreted as a paleo-delta the Sequence I/II boundary. These data were acquired using a Huntec boomer system in 1998. 


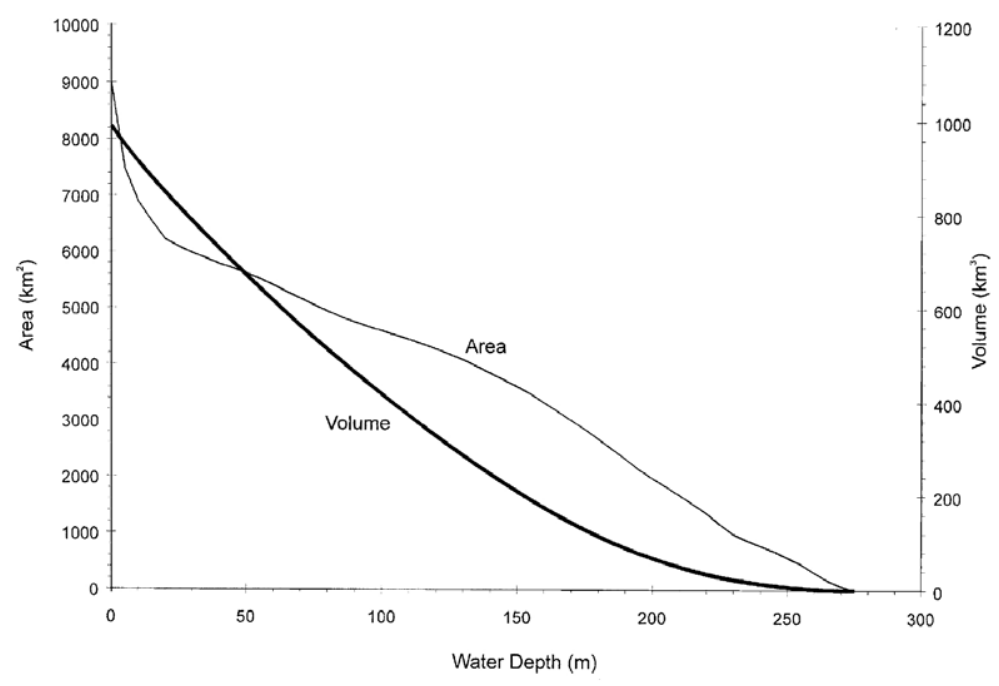

Figure 12. Lake area and volume as a function of water depth for Lake Titicaca.

found on a basinwide scale as much as $240 \mathrm{~m}$ below present lake level, implying that during this event only the deepest parts of the basin were accumulating sediment, while shallower areas were experiencing erosion or a depositional hiatus. We interpret the erosion surface to have formed near the lake surface, which is further substantiated by the presence of clinoforms interpreted as deltaic sequences that have been identified along this sequence boundary using a more powerful seismic source (Figure 11; Seltzer et al., 1999). If the lake level indeed dropped $\sim 240 \mathrm{~m}$, then its volume was decreased by $\sim 80 \%$ and its surface area was reduced from 8,600 to $\sim 2,000 \mathrm{~km}^{2}$ (Figure 12).

Sedimentation rates calculated from core data permit us to estimate the age of the lowstand event by extrapolation. The rate of sedimentation of dated glacial age sediments in deep water averaged about $0.8 \mathrm{~mm} / \mathrm{yr}$ (Baker et al., 2001a). Postglacial sediments accumulated at slower rates of $\sim 0.2 \mathrm{~mm} / \mathrm{yr}$ in the deep part of the lake. If time is equally divided between stadial and interstadial periods (sedimentation rates of 0.8 and $0.2 \mathrm{~mm} /$ yr, respectively), then an average Sequence I/II boundary depth of $30 \mathrm{~m}$ in the deeper areas of the lake, where sediment likely accumulated continuously, implies that the related lowstand occurred at least 90,000 cal yr BP.
The nature of the climatic or tectonic changes that led to the lowstand indicated by this widespread erosional event are unknown. A 240-m tectonic rise of the outlet or subsidence of the basin appears to require improbably high rates of tectonic activity. For example, Quaternary uplift rates in the Bolivian Andes are believed to have been only about $0.7 \mathrm{~mm} / \mathrm{yr}$ (Benjamin et al., 1987). High rates of relative subsidence would also be expected to cause extensive sediment disturbance such as slumps and turbidity flows. Instead, these are remarkably rare. On the contrary, sedimentation seems to have been mostly continuous and uniform after the deposition of Sequence I. Therefore we presume that lake level variation due to climatic change was the dominant factor in producing this lowstand.

Lake level fluctuations on the order of hundreds of meters caused by climatic change have been proposed for other lakes at similar latitudes. For example, Lake Malawi in the East African Rift Valley underwent a lake level drop of 200-300 m between $>40,000$ to $28,000{ }^{14} \mathrm{C}$ yr BP (Finney et al., 1996) and 100-150 m during the early Holocene (Finney and Johnson, 1991). Owen et al. (1990) determined that a 30\% decrease in precipitation was sufficient to account for such a large lake level drop in as little as $400 \mathrm{yr}$ in the East 


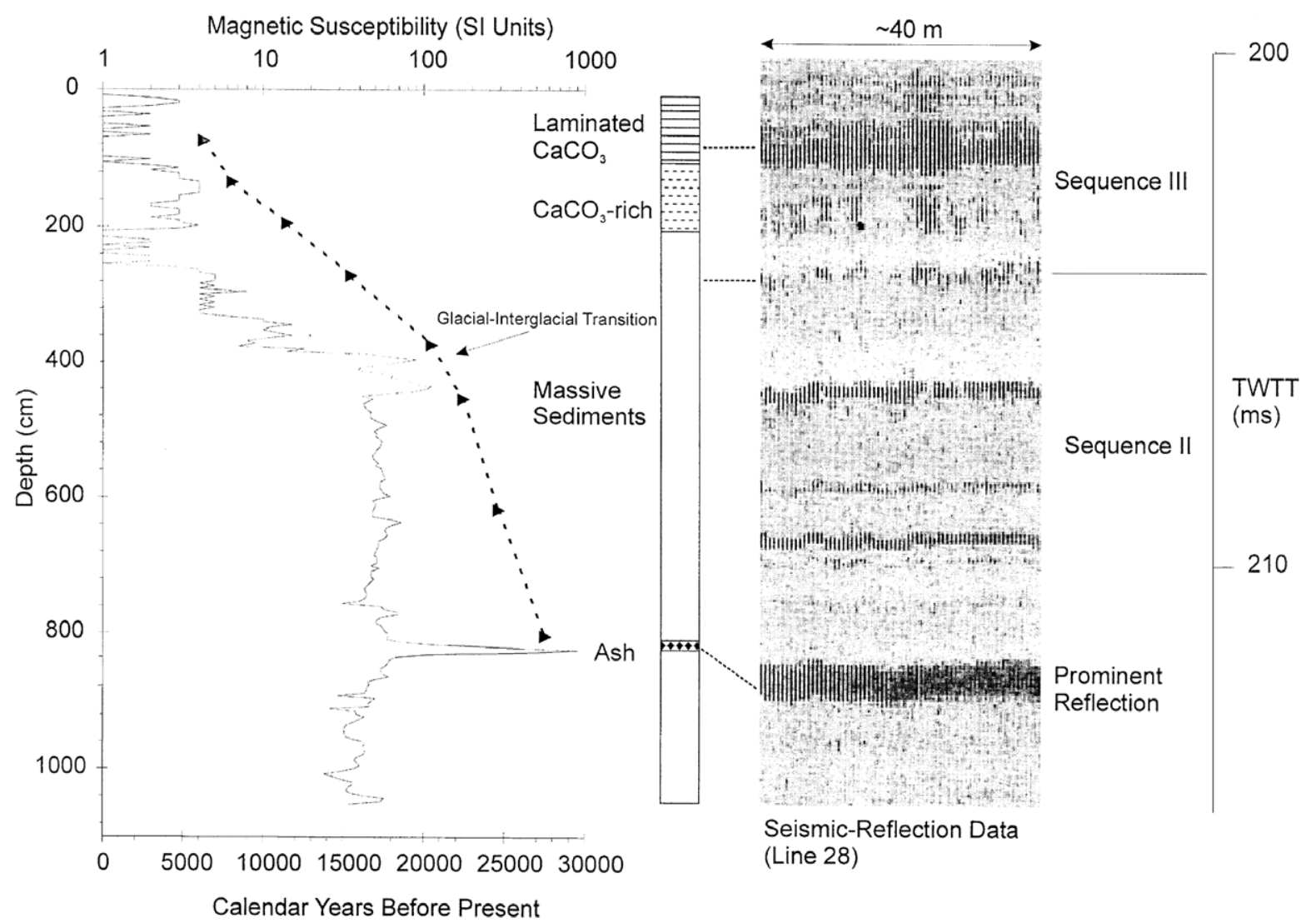

Figure 13. Visual and magnetic susceptibility stratigraphy of sediment core NE981PC in $152 \mathrm{~m}$ water depth correlated with seismic reflection data. The triangles represent AMS radiocarbon dates on bulk organic matter. The magnetic susceptibility spike near the base of the core correlates with an ash layer. This ash has been observed in a number of sediment cores in the basin, and we believe that it correlates with the prominent reflection that occurs at an average sub-bottom depth of 10 $\mathrm{m}$ in the deep areas of the lake. The order-of-magnitude drop in magnetic susceptibility at $\sim 21,000 \mathrm{cal}$ yr BP coincides with a drop in sedimentation rate and with what we believe is the glacial-interglacial transition in this region. At this time glaciers apparently pulled back from their maximum positions, and glacio-fluvial sediments were subsequently trapped in proglacial lakes, which formed in the neighboring cordillera. The carbonate-rich sediments near the top of the core correlate with the middle Holocene lowstand of the lake that is indicated by the sequence boundary at the bottom of Sequence III. At this time the lake was as much as $90 \mathrm{~m}$ below its modern level.

African Rift Valley. The 85-100 m drop of Lake Titicaca in the early to mid Holocene was probably produced by a sustained decrease in effective moisture of $30-40 \%$ compared to modern levels (Cross et al., 2001). The steep-sided morphology of the basin suggests that similar, or slightly greater, moisture decreases could easily result in a greater decrease in lake level and thus in the formation of the deeper erosional surface.

Above Sequence I, the seismic stratigraphy indicates a lake level rise (Sequence II). Paleolake highstands on the southern Altiplano have been studied by Servant and Fontes (1978), Servant et al. (1995), Bills et al. (1994), and Sylvestre et al. (1999). The last two major paleolakes have now been dated in a drill core in the Salar de Uyuni at 15,000-25,000 cal yr BP ("Lago Tauca”) and $>40,000$ cal yr BP ("Lago Minchin”) (Baker et al., 2001b). These ages coincide with past periods of maximum summer insolation and apparently more intense tropical convection (Baker et al., 2001b). It is possible that the onlapping reflectors at the 
base of Sequence II (Parasequence IIa) formed during a rise of Lake Titicaca at the same time as the formation of paleolake Minchin on the southern Altiplano. Above the flooding surface (Parasequence $\mathrm{IIb}$ ), the reflections indicate no major lake level fluctuations, suggesting highstand conditions prevailed until the erosional event at the top of Sequence II.

Within Sequence II (and within Parasequence IIb) there is a prominent reflection. Its depth coincides with the lower limit of the sediment core data that we have available. We believe the prominent reflection is caused by a $\sim 4$-cm-thick ash layer that is present in most of the long cores throughout the basin (Figure 13). The combination of the seismic character of the reflection, the fact that it is not a sequence boundary, and its basinwide presence suggests that the ash layer may in fact be the prominent reflection. The ash layer was bracketed by radiocarbon dates in several sediment cores that place it at 27,000 cal yr BP (Baker et al., 2001a).

The lake level appears to have remained relatively steady until the erosional hiatus that defines the top of Sequence II. Erosion of Sequence II is found in water depths of as much as $90 \mathrm{~m}$ in a number of locations in the lake. Some erosional features, such as channels, associated with this boundary have been discussed previously (Seltzer et al., 1998). These channels contain $<1 \mathrm{~m}$ of sediment that has accumulated since the late-Holocene transgression of the lake level. The lowstands occurred between $\sim 8,000$ and 3,600 cal yr BP (Seltzer et al., 1998; Cross et al., 2000; and Baker et al., 2001a).

The sequence boundaries at the tops of Sequences I and II are defined by erosional surfaces, indicating lake level lowstands. The top of Sequence I, in an average sub-bottom depth of $30 \mathrm{~m}$,

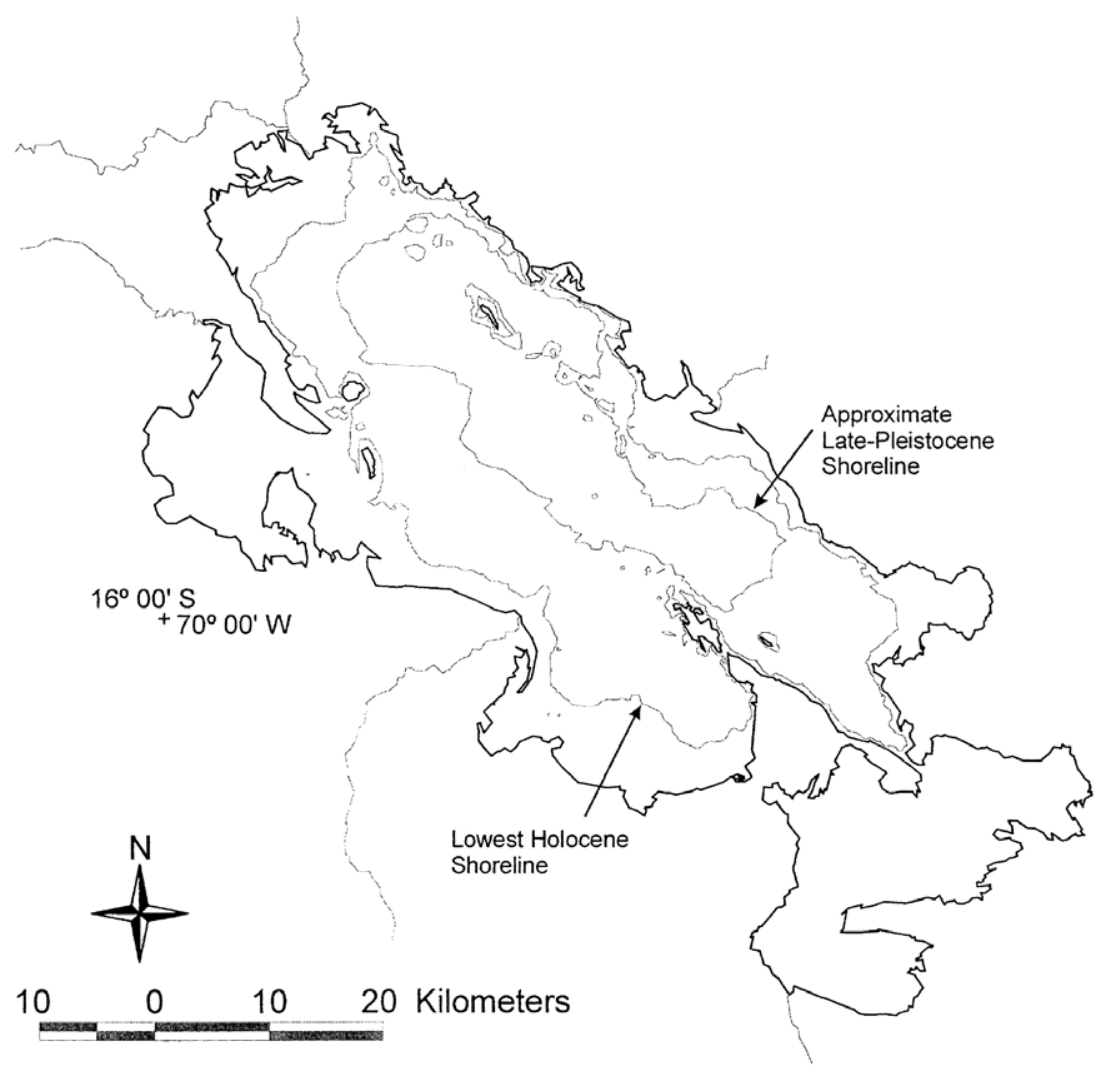

Figure 14. Shorelines at present, $\sim 8,000-3,600 \mathrm{cal}$ yr BP $(-90 \mathrm{~m})$, and $>90,000$ cal yr BP ( $-240 \mathrm{~m})$ based on interpretation of the seismic reflection data. 
indicates that the level of Lake Titicaca was more than 240 m lower than today (>90,000 cal yr BP). A drop in the lake level this large was previously unknown for Lake Titicaca and signals a major late-Pleistocene lowstand. The top of Sequence II, the second erosional boundary, is interpreted as a reflection of the well-documented early- to midHolocene aridity in Lake Titicaca and the tropical Andes (e.g., Seltzer et al., 2000). The seismic reflection profiles show erosional truncation at the base of Sequence III in present water depths as much as $90 \mathrm{~m}$. The approximate aerial extent of both lowstands can be determined using the modern bathymetry of the lake (Figure 14).

Seismic Sequence III represents sediments that have accumulated during the Holocene. These are characterized by organic- and carbonate-rich silts that show a progressive freshening of the lake up to the present (Cross et al., 2000; Baker et al., 2001a). In shallower regions of the lake $(<90 \mathrm{~m})$ this seismic sequence is either missing or thinned because of selective erosion by bottom currents and erosion by subaerial processes in the early to mid Holocene.

\section{Conclusions}

The seismic stratigraphy of Lake Titicaca indicates that late-Quaternary lake levels have varied significantly, most likely because of climatic change. Seismic sequence boundaries dated to $>90,000$ and $\sim 8,000-3,600$ cal yr BP correspond to lake level drops from the modern level of about 240 and $90 \mathrm{~m}$, respectively. Prominent erosional channels in $<90 \mathrm{~m}$ water in the lake bottom are associated with the most recent lake level drop. The seismic data used in conjunction with sediment core data indicate that there is a basinwide stratigraphic marker, most likely volcanic ash, dated at $\sim 27,000$ cal yr BP. Small-scale neotectonic movement of the sediments is indicated by normal faults, some of which penetrate the sediment-water interface. However, evidence for slumping and deformation of the sediments associated with major tectonic activity is lacking in the seismic reflection data.

\section{Acknowledgements}

We would like to thank N. Catari, S. Cross, G. Mollericon, and D. Mucciarone for help in acquisition of the seismic data; Ing. J. Sanjines and Ing. M. Revello of the Autoridad Autonoma de Lago Titicaca, La Paz, for the necessary permission to conduct research on the lake and for invaluable logistical assistance; J. Halfman and D. Woodrow of The Hobart and William Smith Colleges for loan of the X-Star sub-bottom profiling system; and F. Anselmetti, M. De Batist, S. Colman, and C. Scholz for critical reviews of the manuscript. This research was supported by US NSF Grants ATM9600051 to G.S., ATM-9619672 to P.B., ATM9708256 to S.F., and ATM-9624715 to R.D.

\section{References}

Аввотт et AL., 1997. M. Abbott, M. Binford, M. Brenner and K. Kelts, A $3500{ }^{14} \mathrm{C}$ yr high-resolution record of lake level changes in Lake Titicaca, Bolivia/Peru. Quat. Res. 47 (1997), pp. 169-180.

BAKer et AL., 2001a. P.A. Baker, G.O. Seltzer, S.C. Fritz, R.B. Dunbar, M.J. Grove, P.M. Tapia, S.L. Cross, H.D. Rowe and J.P. Broda, The history of South American tropical precipitation for the past 25,000 years. Science 291 (2001), pp. 640-642.

Baker et AL., 2001b. P.A. Baker, C.A. Rigsby, G.O. Seltzer, S.C. Fritz, T.K. Lowenstein, N.P. Bacher and C. Veliz, Tropical climate changes at millennial and orbital timescales revealed by deep drilling on the South American Altiplano. Nature 409 (2001), pp. 698-701.

Benjamin et al., 1987. M. Benjamin, N. Johnson and C. Naeser, Recent rapid uplift in the Bolivian Andes; evidence from fission-track dating. Geology 15 (1987), pp. 680-683.

Bills ET AL., 1994. B. Bills, S. de Silva, D. Currey, R. Emenger, K. Lillquist, A. Donnellan and B. Worden, Hydro-isostatic deflection and tectonic tilting in the Central Andes; initial results of a GPS survey of Lake Minchin shorelines. Geophys. Res. Lett. 21 (1994), pp. 293-296.

Binford et AL., 1997. M.W. Binford, A.L. Kolata, M. Brenner, J.W. Janusek, M.T. Seddon, M. Abbott and J.H. Curtis, Climate variation and the rise and fall of an Andean civilization. Quat. Res. 47 (1997), pp. 235-248.

Boulangé And Aquize Jean, 1981. B. Boulangé and E. Aquize Jean, Morphologie, hydrographie et climatologie du Lac Titicaca et de son bassin versant. Rev. Hydrobiol. Trop. 14 (1981), pp. 269-287.

Boulangé et Al., 1981. B. Boulangé, C. Vargas and L.A. Rodrigo, La sédimentation actuelle dans le lac Titicaca. Rev. Hydrobiol. Trop. 14 (1981), pp. 299-309. 
Cross et AL., 2000. S. Cross, P. Baker, G. Seltzer, S. Fritz and R. Dunbar, A new estimate of the Holocene lowstand level of Lake Titicaca and implications for tropical paleohydrology. Holocene 10 (2000), pp. 21-32.

Cross et AL., 2001. S. Cross, P.A. Baker, G.O. Seltzer, S.C. Fritz and R.B. Dunbar, Isotopic and chemical modeling of Lake Titicaca: toward a better understanding of late Quaternary climate and hydrology of the tropics of South America. Quat. Res. 56 (2001), pp. 1-9.

D’Agostino, 1998. D’Agostino, K., 1998. Late Quaternary High-resolution Seismic Stratigraphy of Lake Titicaca (Peru/Bolivia). M.S. Thesis, Syracuse University, Syracuse, NY.

Finney ET AL., 1996. Finney, B., Scholz, C., Johnson, T., Trumbore, S., 1996. Late Quaternary lake-level changes of Lake Malawi. In: Johnson, T.C., Odada, E. (Eds.), The Limnology, Climatology and Paleoclimatology of the East African Lakes, Gordon and Beach, Toronto, pp. 495-521.

Finney And Johnson, 1991. B.P. Finney and T.C. Johnson, Sedimentation in Lake Malawi (East Africa) during the past 10000 years: a continuous paleoclimatic record from the southern tropics. Palaeogeogr. Palaeoclimatol. Palaeoecol. 85 (1991), pp. 351-366.

Kessler, 1985. A. Kessler, Zur Rekonstruktion von spaetglazialem Klima und Wasserhaushalt auf dem peruanisch-bolivianischen Altiplano. Z. Gletsch.kd. Glazialgeol. 21 (1985), pp. 107-114.

Lavenu, 1992. Lavenu, A., 1992. Formation and geological evolution. In: Dejoux, C., Iltis, A. (Eds.), Lake Titicaca: A Synthesis of Limnological Knowledge. Kluwer Academic, Dordrecht, pp. 3-15.

Mercer, 1984. Mercer, J.H., 1984. Late Cainozoic glacial variation in South America south of the Equator. In: Vogel, J.C. (Ed.), Late Cainozoic Paleoclimates of the Southern Hemisphere. A.A. Balkema, Rotterdam, pp. 45-58.

Newell, 1949. Newell, N., 1949. Geology of the Lake Titicaca region. Geol. Soc. Am. Mem. 36, 111 pp.

Owen et Al., 1990. R. Owen, R. Crossley, T. Johnson, D. Tweddles, I. Kornfield, S. Davidson, D. Eccles and D. Engstrom, Major low levels of Lake Malawi and implications for speciation rates in cichlid fishes. Proc. $R$. Soc. London 240 (1990), pp. 519-553.

Roche et AL., 1992. Roche, M.-A., Bourges, J., Cortes, J., Mattos, R., 1992. Climatology and hydrology of the Lake Titicaca basin. In: Dejoux, C., Iltis, A. (Eds.), Lake Titicaca: A Synthesis of Limnological Knowledge. Kluwer Academic, Dordrecht, MOBI vol. 68, pp. 63-88.

Sebrier et AL., 1985. M. Sebrier, J.L. Mercier, F. Megard, G. Laubacher and E. Carey-Gailhardis, Quaternary normal and reverse faulting and the state of stress in the central Andes of south Peru. Tectonics 4 (1985), pp. 739-780.

Seltzer et AL., 1999. G.O. Seltzer, P. Baker, S. Colman, R. Thieler, R. Dunbar and S. Fritz, Late Quaternary lake level variation in the Peruvian-Bolivian Altiplano. EOS AGU Fall Meet. Abstr. 80 (1999), p. F4.

Seltzer et Al., 2000. G.O. Seltzer, D.T. Rodbell and S. Burns, Isotopic evidence for late Quaternary climatic change in tropical South America. Geology 28 (2000), pp. 35-38.

SeLtzer, 1992. G.O. Seltzer, Late Quaternary glaciation of the Cordillera Real, Bolivia. J. Quat. Sci. 7 (1992), pp. 87-98.

Seltzer, 1994. G.O. Seltzer, A lacustrine record of latePleistocene climatic change in the subtropical Andes. Boreas 23 (1994), pp. 105-111.

Seltzer et AL., 1998. G. Seltzer, P. Baker, S. Cross, R. Dunbar and S. Fritz, High-resolution seismic reflection profiles from Lake Titicaca, Peru-Bolivia: Evidence for Holocene aridity in tropical Andes. Geology 26 (1998), pp. 167-170.

Servant and Fontes, 1978. M. Servant and J. Fontes, Les lacs quaternaires des hauts plateaux des Andes boliviennes. Prem. Interpret. Paléoclim. Cah. O.R.S.T.O.M., Sér. Géol. 10 (1978), pp. 9-23.

Servant et AL., 1995. M. Servant, M. Fournier, J. Argollo, S. Servant-Vildary, F. Sylvestre, D. Wirrman and J.P. Ybert, La dernière transition glaciaire/interglaciaire des Andes tropicales sud (Bolivie) d'apres l'étude des variations des niveaux lacustres et des fluctuations glaciaires. C.R. Acad. Sci. Paris 320 (1995), pp. 729-736.

Sylvestre eT AL., 1999. F. Sylvestre, M. Servant, S. Servant-Vildary, C. Causse, M. Fournier and J.P. Ybert, Lake-level chronology on the southern Bolivian Altiplano $\left(18^{\circ}-23^{\circ} \mathrm{S}\right)$ during late-Glacial time and the early Holocene. Quat. Res. 51 (1999), pp. 54-66.

VAIl ET AL., 1977. Vail, P., Mitchum, R., Todd, R., Widmier, J., Thompson, S. III, Sangree J., Bubb, J., Hatelid W., 1977. Seismic stratigraphy and global changes of sea level. In: Payton, C. (Ed.), Seismic Stratigraphy - Applications to Hydrocarbon Exploration. AAPG Mem. 26, 49-205.

VAIL, 1987. Vail, P., 1987. Seismic stratigraphy interpretation procedure. In: Bally, A. (Ed.), Atlas of Seismic Stratigraphy. AAPG Studies in Geology 27, American Association of Petroleum Geologists, Washington, DC.

Wirrman, 1992. Wirrman, D., 1992. Morphology and bathymetry. In: Dejoux, C., Iltis, A. (Eds.), Lake Titicaca. A Synthesis of Limnological Knowledge. Kluwer Academic, Dordrecht, MOBI vol. 68, pp. 16-22.

Wirrman and De Olivera Almeida, 1987. D. Wirrman and L. De Olivera Almeida, Low Holocene level (7700 to 3650 years ago) of Lake Titicaca (Bolivia). Palaeogeogr. Palaeoclimatol. Palaeoecol. 59 (1987), pp. 315-323.

Wirrman et al., 1992. Wirrman, D., Ybert, J.-P., Mourguiart, P., 1992. A 20000 years paleohydrological record from Lake Titicaca. In: Dejoux, C., Iltis, A. (Eds.), Lake Titicaca: A Synthesis of Limnological Knowledge. Kluwer Academic, Dordrecht, MOBI vol. 68, pp. $16-22$. 